\title{
Comparative evaluation of various scoring systems to predict prognosis in patients with acute biliary pancreatitis
}

\author{
Akut biliyer pankreatitli hastalarda prognozu öngörmede çeşitli skorlama sistemlerinin karşılaştırmalı \\ değerlendirilmesi
}

\author{
(D) Gökhan TAZEGÜL' ${ }^{1}$ (D Mete AKIN², (DBülent YILDIRIM² \\ Departments of ${ }^{1}$ Internal Medicine and ${ }^{2}$ Gastroenterology, Akdeniz University School of Medicine, Antalya
}

\begin{abstract}
Background and Aims: To identify the severity of pancreatitis in patients diagnosed with acute biliary pancreatitis, and it also seeks to assess the congruence between the revised Atlanta classification and clinical and laboratory findings and prognostic scoring systems. Materials and Methods: A total of sixty-six patients with biliary pancreatitis were evaluated with revised Atlanta classification. Ranson score, Glasgow-Imrie score, Bedside Index of Severity in Acute Pancreatitis, Harmless Acute Pancreatitis Score, Japanese Severity Score, Acute Physiology and Chronic Health Evaluation-II, Sequential Organ Failure Assessment score, albumin-bilirubin grade were evaluated and compared, along with clinical and laboratory findings. SPSS Windows version 23.0 and Medcalc 19.2 were used in the analysis. Results: Bedside Index of Severity in Acute Pancreatitis had the highest correlation coefficient in differentiating moderate and severe pancreatitis. Glasgow-Imrie, albumin-bilirubin grade (48 h) and Japanese Severity Score score and Sequential Organ Failure Assessment score were also moderately correlated. Albumin-bilirubin grade (admission) and Harmless Acute Pancreatitis Score were weakly correlated. No correlation was found with the Ranson score and Acute Physiology and Chronic Health Evaluation score. The presence of albumin-bilirubin grade 3 at 48th hour increases the risk of moderate and severe pancreatitis by 17 times. Presence of antibiotic use increases the risk 6.6 times and positive Bedside Index of Severity in Acute Pancreatitis score increases the risk 4.7 times. Conclusion: The use of multiple scoring systems or co-evaluation of laboratory data can increase the sensitivity and specificity of clinical decisions. Combined use of Bedside Index of Severity in Acute Pancreatitis and antibiotherapy requirement is a candidate for predicting moderate and severe pancreatitis. Further studies on albumin-bilirubin grade, especially in acute biliary pancreatitis, are necessary.
\end{abstract}

Key words: Pancreatitis, biliary pancreatitis, prognosis, prognostic scores

\section{INTRODUCTION}

Acute pancreatitis refers to a heterogeneous group of diseases with different etiologies (1). Episodes can assume a mild or severe course, which can result in mortality. Therefore, identifying patients who will require aggressive treatment and being able to predict at the time of admission which patients will have a severe course is im-

Correspondence: Gökhan TAZEGÜL

Department of Internal Medicine, Akdeniz University Faculty of Medicine, Antalya/Turkey

E-mail: drgtazegul@gmail.com
Giriş ve Amaç: Bu çalışmada, (i) akut biliyer pankreatitli hastalarda pankreatitin şiddetini belirlemek, (ii) revize edilmiş Atlanta sınıflandırmasına göre şiddet ile klinik ve laboratuvar bulgular ve prognostik skorlama sistemlerinin uyumunun değerlendirilmesi amaçlanmıştır. Gereç ve Yöntem: Çalışmada, biliyer pankreatit tanısı almış toplam altmış altı hasta revize Atlanta sınıflandırması ile değerlendirilmiştir. Ranson skoru, Glasgow-Imrie skoru, Yatak Başı Akut Pankreatit Şiddet Indeksi (Bedside Index of Severity in Acute Pancreatitis), Zararsiz Akut Pankreatit Skoru, Japon Şiddet Skoru, Akut Fizyoloji ve Kronik Sağlık Değerlendirme (Acute Physiology and Chronic Health Evaluation-II), Ardışık Organ Yetmezliği Değerlendirmesi (Sequential Organ Failure Assessment) skoru ve albümin-bilirübin skoru değerlendirilmiş; klinik ve laboratuvar bulguları ile karşılaştırılmıştır. Analizde, SPSS Windows sürüm 23.0 ve Medcalc 19.2 kullanılmıştır. Bulgular: Yatak Başı Akut Pankreatit Şiddet Indeksi, orta ve şiddetli pankreatiti ayırt etmede en yüksek korelasyon katsayısına sahipti. Glasgow-Imrie, albümin-bilirübin skoru (48 saat), Japon Şiddet Skoru skoru ve Ardışık Organ Yetmezliği Değerlendirmesi skoru da orta derecede korelasyona sahipti. Albümin-bilirübin skoru (başvuru) ve Zararsız Akut Pankreatit Skoru zayıf bir şekilde korele saptandı. Ranson skoru ve Akut Fizyoloji ve Kronik Sağlık Değerlendirme skoru ile pankreatit şiddeti arasında herhangi bir korelasyon bulunmadı. 48. saatte albümin-bilirübin grade 3 varlığı, orta ve şiddetli pankreatit riskini 17 kat arttırmaktaydı. Antibiyotik kullanım gerekliliğinin riski 6.6 kat, Yatak Başı Akut Pankreatit şiddet Indeksi skoru pozitifliğinin ise riski 4.7 kat arttırmakta olduğu gösterilmiştir. Sonuç: Skorlama sistemlerinin çoklu kullanılması veya laboratuvar verileri ile beraber değerlendirilmesi, klinik kararların duyarlıığını ve özgüllüğünü arttırabilir. Yatak Başı Akut Pankreatit Şiddet Indeksi ve antibiyoterapi gerekliliğinin kombine kullanımı, orta ve şiddetli pankreatiti tahmin etmeye aday bir çoklu kullanım örneğidir. Özellikle akut biliyer pankreatitte albümin-bilirübin skoru ile ilgili daha ileri çalışmalar gereklidir.

Anahtar kelimeler Pankreatit, biliyer pankreatit, prognoz, prognostik skorlar

portant for predicting the risk of developing permanent organ failure and local complications (2).

Given the current literature on organ failure and pancreatic necrosis, the revised Atlanta classification was established in 2012 (3). Mild acute pancreatitis constitute the group that heals completely in no later than a week, of-

Tazegül G, Akın M, Yıldırım B. Comparative evaluation of various scoring systems to predict prognosis in patients with acute biliary pancreatitis. The Turkish Journal of Academic Gastroenterology 2021;20:32-43. DOI: 10.17941/ agd.931014

Manuscript Received: 03.12.2020 • Accepted: 21.02.2021 
ten without the need for imaging, and has a low mortality rate (4). Moderate pancreatitis accounts for $15-20 \%$ of all pancreatitis cases, mortality in this group reaches $10 \%$ (5). Severe pancreatitis accounts for less than 10\% of all pancreatitis cases, and mortality can range between 35-50\%, with early and late complications (6).

Various scoring systems including Pancreatitis-specific Ranson score, Glasgow-Imrie score, Bedside Index of Severity in Acute Pancreatitis (BISAP), Harmless Acute Pancreatitis Score (HAPS), and Japanese Severity Score (JSS), whose advantages and disadvantages differ from each other, have been defined to predict which patients will develop moderate or severe pancreatitis (7-10). Acute Physiology and Chronic Health Evaluation-II (APACHE-II) and Sequential Organ Failure Assessment (SOFA) scores, which are not specific for pancreatitis and have been defined in association with patient mortality and organ failure in intensive care, may also be associated with severity and prognosis in acute pancreatitis $(11,12)$. In a recent publication, in addition to these scores, it was demonstrated that albumin-bilirubin ( $A L B I$ ) grading, a useful score of evaluate liver function and a grading system used in hepatocellular cancer, may also be prognostically significant (13). In addition to prognostic scores, there are comparative studies showing that acute phase indicators such as neutrophil lymphocyte ratio (NLR), C-reactive protein (CRP), and procalcitonin levels can also predict severe acute pancreatitis, pancreatic necrosis, organ failure, and mortality $(14,15)$.

The aim of this study was to identify the severity of pancreatitis in patients diagnosed with acute biliary pancreatitis, and it also seeks to assess the congruence between the revised Atlanta classification and clinical and laboratory findings and prognostic scoring systems.

\section{MATERIALS and METHODS}

This study was conducted in accordance with the Declaration of Helsinki. Ethics committee approval was received from Akdeniz University Faculty of Medicine Ethics Committee (30.05.2018/382). Informed consent was obtained from the patients for the use of information.

\section{Selection of Patients}

Patients who followed up with the diagnosis of acute biliary pancreatitis at the Gastroenterology Clinic of Akdeniz University Medical Faculty Hospital between June 2017 and June 2018 were retrospectively evaluated. Diagnosis of acute pancreatitis was made according to the revised Atlanta classification, and the presence of at least two of the diagnostic criteria (abdominal pain typical for pancre- atitis, amylase and/or lipase concentration at least three times higher than the upper limit, and imaging findings specific to pancreatitis) was diagnosed as acute pancreatitis (3). Patients, aged 18 years and above, whose diagnosis of biliary pancreatitis was confirmed by laboratory and imaging methods followed by at least 48 hours of hospitalization, and those whose laboratory and imaging data were planned to be evaluated were included in the study. Patients with chronic pancreatitis, diagnosed with exocrine or endocrine pancreatic insufficiency, hospitalized due to early period pancreatitis relapse (within 90 days), with local and/or systemic complication due to previous pancreatitis, with history of hepato-pancreato-biliary surgery, pregnant or postpartum patients, patients with advanced stage organ failure before pancreatitis (recent chronic renal failure, patients with congestive heart failure...) were excluded from the study.

\section{In-house Rules for Routine Management of Pancreatitis}

Patients who applied to our center with a diagnosis of pancreatitis were followed up with for at least 48 hours after hospitalization except patients who withdrew their consent. Admission and 48th hour examinations were routinely performed. Information necessary for scoring were recorded in patient files. Narcotic analgesics were administered to patients with a visual analog scale (VAS) score of 5 and above, despite paracetamol and/or non-steroidal anti-inflammatory therapy in the hospitalization process. VAS scores were followed at intervals of 6 hours. Decisions on starting oral intake, discharge, blood culture, and starting antibiotic therapy were undertaken by a consultant clinician (an expert gastroenterologist). Patients with suspicion of concomitant sepsis were routinely sampled and antibiotic therapy was started.

\section{Recording Patient Data}

Demographic, clinical, and laboratory data of the patients were retrospectively obtained from patient files and hospital information system. Patients' age, gender, comorbidity, history of abdominal surgery, number of pancreatitis episodes, duration of hospitalization (days), use of antibiotic therapy during hospitalization, blood culture results, examination findings and visual analog scale (VAS) scores recorded for pain at the time of admission and $48^{\text {th }}$ hour, and the total amount of narcotic analgesics used were recorded. Narcotic analgesic doses were calculated based on equivalent doses of morphine (16). 
For laboratory findings, hemoglobin $(\mathrm{g} / \mathrm{dL})$, platelet $\left(10^{3} /\right.$ $\mu \mathrm{L})$, leukocytes $\left(10^{3} / \mu \mathrm{L}\right)$, neutrophils $\left(10^{3} / \mu \mathrm{L}\right)$, lymphocytes $\left(10^{3} / \mu \mathrm{L}\right)$ levels, neutrophil-to-lymphocyte ratio (NLR), sedimentation ( $\mathrm{mm} / \mathrm{h}$ ), blood-urea-nitrogen (BUN, $\mathrm{mg}$ / $\mathrm{dL})$, creatinine $(\mathrm{mg} / \mathrm{dL})$, albumin $(\mathrm{g} / \mathrm{dL})$, aspartate aminotransferase (AST, $\mathrm{U} / \mathrm{L}$ ), alanine aminotransferase (ALT, $\mathrm{U} / \mathrm{L}$ ), gamma-glutamyl transferase (GGT, U/L), alkaline phosphatase $(A L P, U / L)$, lactate dehydrogenase $(L D H, U / L)$, total bilirubin $(\mathrm{mg} / \mathrm{dL})$, direct bilirubin $(\mathrm{mg} / \mathrm{dL})$, amylase $(\mathrm{U} / \mathrm{L})$, lipase (U/L), C-reactive protein (CRP, $\mathrm{mg} / \mathrm{dL})$, and procalcitonin $(\mathrm{ng} / \mathrm{mL})$ results at admission and $48^{\text {th }}$ hour were recorded.

\section{Prognostic Scoring Systems Used}

Patients were classified according to the revised Atlanta classification: mild (organ failure, no local or systemic complications), moderate (less than 48 hours of organ failure or local or systemic complications without persistent organ failure), and severe pancreatitis (dysfunction of one or more organs lasting more than 48 hours) (3).

For the Ranson score, 10 findings identified for acute biliary pancreatitis were used. Only 9 clinical findings were taken into evaluation for the JSS scoring, and imaging findings were not evaluated as imaging was not performed for all patients. The presence of at least three of the listed factors for Ranson, Glasgow-Imrie, and JSS scores was considered positive $(7,10,17)$. The presence of at least two factors was considered positive for BISAP scoring and the presence of any one factor was considered positive for HAPS scoring $(8,9)$. Predetermined grades in the literature were used for ALBI grade (Grade 1: $\leq-2.60$, Grade 2: $>-2.60$ to $\leq-1.39$, and Grade 3: $>-1.39$ ), and Grade 3 patients were considered positive (Table 1) (13). The cut-off value was 8 for APACHE positivity and 4 for SOFA positivity $(11,12)$.

\section{Statistical Analysis}

SPSS Windows version 23.0 was used in the analysis of data. DeLong test was performed using Medcalc 19.2 for diagnostic test evaluation and pairwise comparison of ROC curves. Continuous variables were expressed as median (minimum-maximum) and categorical variables were expressed as number and percentage. Chi-square test was used to evaluate the relationship between categorical data and Mann-Whitney $U$ test was used for intergroup evaluation of continuous variables.

In addition to Chi-Square test, phi correlation coefficient was used to examine the associations of categorical variables. Correlation coefficient was evaluated as follows: 0-0.3 "weak", 0.3-0.5 "medium", and 0.5-1 "strong." Univariate and multivariate logistic regression analyses were used to evaluate the relationship between categorical and continuous variables and categorical results. In order to homogenize the data in multivariate regression analysis, clinical findings, laboratory findings, and scoring systems were grouped separately and the Backwards-Wald method was performed, and variables with statistical significance in each group were evaluated again by multivariate regression analysis. Data in all groups were then evaluated together and modeled. The reciever operator characteristics curve (ROC) analysis and curve method was used to determine the cut-off value for the tests and calculate the area under the curve (AUC). P $<0.05$ was considered significant for all statistical tests.

\section{RESULTS}

A total of sixty-six patients with biliary pancreatitis were included in the study. According to the revised Atlanta classification, 46 of these patients $(69.6 \%)$ were classified as mild, 13 as moderate (19.6\%), and 7 (10.8\%) were classified to be having severe pancreatitis.

Clinical and demographic data of patients according to the revised Atlanta classification are presented in Table 2. Patients with severe pancreatitis were 18 years older than patients with moderate and mild pancreatitis (Mann-Whitney $U$ test, $p=0.03$ ). $30.4 \%$ of patients with mild pancreatitis received in-patient treatment for more than 5 days, whereas this ratio was $76.9 \%$ for patients with moderate pancreatitis and $100 \%$ for patients with severe pancreatitis. Patients with mild pancreatitis were hospitalized for 5 days less than patients with moderate and severe pancreatitis (Mann-Whitney $U$ test, $p=$ $0.001)$. In the moderate and severe pancreatitis group, antibiotic therapy requirement was 2 times more frequent compared to mild pancreatitis group (Chi-Square test, $p=0.001)$. Similarly, reproduction in blood culture was detected 2 times more often in moderate pancreatitis group and 3 times more often in severe pancreatitis group (Chi-Square test, $p=0.002$ ). Although the VAS scores of patients were similar on admission, pain persistence at $48^{\text {th }}$ hour was 3 times more frequent in the moderate and severe pancreatitis group (Chi-Square test, $p=0.003)$. In accordance with this finding, the use of narcotic analgesics was also more frequent in these groups (Chi-Square test, $p=0.01$ ).

Laboratory data of patients on admission and at $48^{\text {th }}$ hour according to the revised Atlanta classification are presented in Tables 3 and 4. In patients with mild pancreatitis, NLR (Mann-Whitney $U$ test, $p=0.03$ and 0.002 , respectively), CRP (Mann-Whitney $U$ test, $p=0.016$ and 0.02 , respectively), and procalcitonin (Mann-Whitney-U test, $p=0.008$ and 0.01 , respectively) levels on admission and at $48^{\text {th }}$ hour were lower compared to patients with moderate and severe pancreatitis. 
Table 1. Pancreatitis scoring systems used in the study

\begin{tabular}{|c|c|}
\hline $\begin{array}{l}\text { Ranson Score for biliary } \\
\text { pancreatitis (7) }\end{array}$ & $\begin{array}{l}\text { On admission } \\
\begin{array}{ll}\text { - } & \text { Age }>70 \\
\text { - } & \text { Glucose }>220 \mathrm{mg} / \mathrm{dL} \\
\text { - } & \text { Leukocyte }>18000 / \mathrm{mm}^{3} \\
\text { - } & \text { AST }>250 \mathrm{U} / \mathrm{L} \\
\text { - } & \text { LDH }>400 \mathrm{U} / \mathrm{L}\end{array}\end{array}$ \\
\hline $\begin{array}{l}\text { Within } 48 h \\
\text { Positive } \geq 3\end{array}$ & $\begin{array}{l}\mathbf{4 8}^{\text {th }} \text { hour } \\
\text { - } \text { BUN increase }>2 \mathrm{mg} / \mathrm{dL} \\
\text { - } \text { Base deficit }>5 \mathrm{mEq} / \mathrm{L} \\
\text { - } \text { Hematocrit decline }>10 \% \\
\text { - } \text { Calcium }<8 \mathrm{mg} / \mathrm{dL} \\
\text { - } \\
\text { Fluid loss }>4 \mathrm{Lt}\end{array}$ \\
\hline $\begin{array}{l}\text { Glasgow-Imrie Score } \\
(17) \\
\text { Within } 48 \mathrm{~h} \\
\text { Positive } \geq 3\end{array}$ & 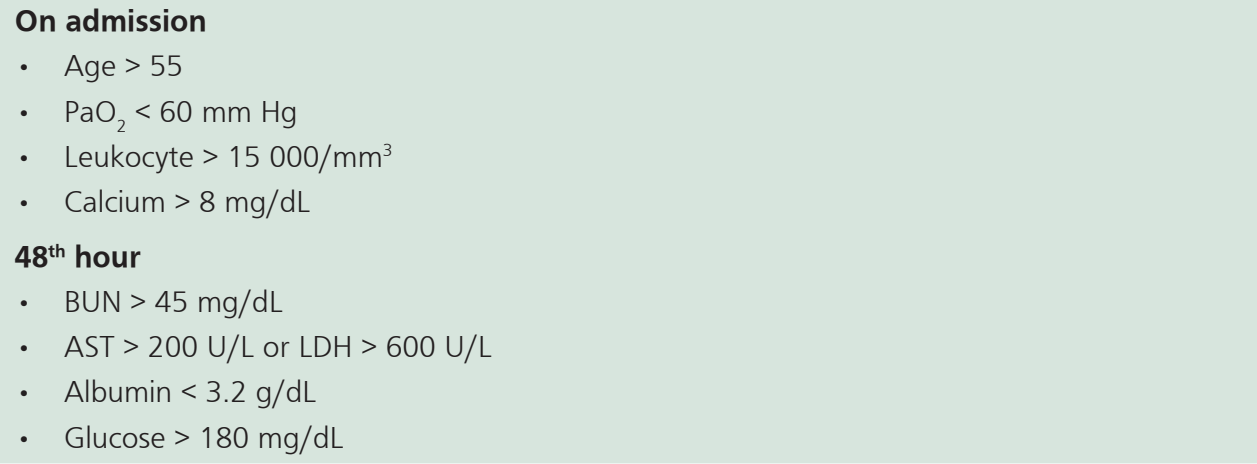 \\
\hline $\begin{array}{l}\text { JSS score (10) } \\
\text { Within } 24 \text { h } \\
\text { Positive } \geq 3\end{array}$ & 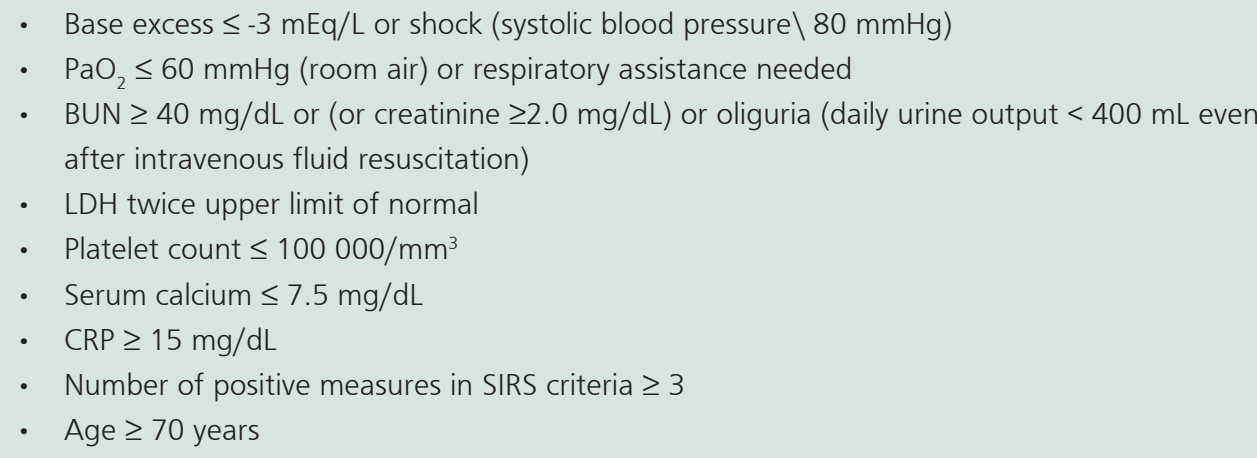 \\
\hline $\begin{array}{l}\text { BISAP score (8) } \\
\text { Within } 24 \mathrm{~h} \\
\text { Positive } \geq 2\end{array}$ & $\begin{array}{ll}\text { - } & \text { Age }>60 \\
\text { - } & \text { BUN }>25 \mathrm{mg} / \mathrm{dL} \\
\text { - } & \text { SIRS findings } \\
\text { - } & \text { Mental disorder (disorientation, lethargy...) } \\
\text { - } & \text { Pleural effusion }\end{array}$ \\
\hline $\begin{array}{l}\text { HAPS score (9) } \\
\text { On admission } \\
\text { Positive if any present }\end{array}$ & $\begin{array}{l}\text { - Peritonitis (defender or rebound sensitivity) } \\
\text { - Creatinine }>2 \mathrm{mg} / \mathrm{dL} \\
\text { - Hematocrit ( } \geq 43 \% \text { in men, } 39.6 \% \text { in women) }\end{array}$ \\
\hline $\begin{array}{l}\text { ALBI grade (13) } \\
\text { Positive if Grade } 3\end{array}$ & $\begin{array}{l}(\log 10 \text { bilirubin } \times 0.66)+(\text { albumin } \times-0.085) \\
\text { - } \quad \text { Grade } 1=\leq-2.60 \\
\text { - } \quad \text { Grade } 2=>-2.60 \text { to } \leq-1.39 \\
\text { - } \quad \text { Grade } 3=>-1.39\end{array}$ \\
\hline
\end{tabular}

JSS: Japanese Severity Score, BISAP: Bedside Index of Severity in Acute Pancreatitis, HAPS: Harmless Acute Pancreatitis Score, ALBI: Albumin-bilirubin grade, AST: Aspartate aminotransferase, LDH: Lactate dehydrogenase, BUN: Blood-urea-nitrogen, SIRS: Systemic inflammatory response syndrome, CRP: C-reactive protein. 
Table 2. Demographic and clinical follow-up data of patients according to Atlanta classification.

\begin{tabular}{|c|c|c|c|c|}
\hline & & $\begin{array}{c}\text { Mild } \\
(n=46)\end{array}$ & $\begin{array}{c}\text { Moderate } \\
(n=13)\end{array}$ & $\begin{array}{l}\text { Severe } \\
(n=7)\end{array}$ \\
\hline Age (years) & & $55(21-90)$ & $58(37-88)$ & $76(34-97)$ \\
\hline Gender & Female & $24(52.2 \%)$ & $9(69.2 \%)$ & $5(71.4 \%)$ \\
\hline \multicolumn{5}{|l|}{ Concomitant disease } \\
\hline & Respiratory & $3(6.5 \%)$ & $0(0 \%)$ & $0(0 \%)$ \\
\hline & Cardiovascular & $4(8.7 \%)$ & $6(46.2 \%)$ & $1(14.3 \%)$ \\
\hline & Rheumatologic & $5(10.9 \%)$ & $0(0 \%)$ & $1(14.3 \%)$ \\
\hline & Endocrine & $3(6.5 \%)$ & $0(0 \%)$ & $0(0 \%)$ \\
\hline & Multiple diseases & $16(34.8 \%)$ & $3(23.1 \%)$ & $4(57.1 \%)$ \\
\hline Previous abdominal surgery & & $13(28.3 \%)$ & $3(23.1 \%)$ & $2(28.6 \%)$ \\
\hline \multirow[t]{2}{*}{ Number of episodes } & First episode & $29(63 \%)$ & $8(61.5 \%)$ & $4(57.1 \%)$ \\
\hline & Multiple episodes & $17(37 \%)$ & $5(38.5 \%)$ & $3(42.9 \%)$ \\
\hline \multirow[t]{2}{*}{ Duration of hospitalization (days) } & & $4(2-17)$ & $9(2-18)$ & $10(6-16)$ \\
\hline & $>5$ days & $14(30.4 \%)$ & $10(76.9 \%)$ & $7(100 \%)$ \\
\hline Antibiotherapy requirement & & $21(45.7 \%)$ & $11(84.6 \%)$ & $7(100 \%)$ \\
\hline Reproduction in blood culture & & $3(15.8 \%)$ & $3(33.3 \%)$ & $3(42.9 \%)$ \\
\hline \multirow[t]{2}{*}{ VAS score on admission } & & $8(3-10)$ & $9(4-10)$ & $7(6-10)$ \\
\hline & $>5$ & $36(78.3 \%)$ & $12(92.3 \%)$ & $7(100 \%)$ \\
\hline \multirow[t]{2}{*}{ VAS score at $48^{\text {th }}$ hour } & & $0(0-5)$ & $3(0-5)$ & $3(0-5)$ \\
\hline & Persistent pain & $13(28.3 \%)$ & $9(69.2 \%)$ & $5(71.4 \%)$ \\
\hline \multirow[t]{2}{*}{ Dosage of narcotic analgesics } & mg-morphine eq. & $5(0-40)$ & $20(0-45)$ & $15(10-30)$ \\
\hline & Narcotic use & $31(67.4 \%)$ & $12(92.3 \%)$ & $7(100 \%)$ \\
\hline \multirow[t]{5}{*}{ Organ failure } & & - & - & - \\
\hline & Renal & - & $6(46.1 \%)$ & $1(14.3 \%)$ \\
\hline & Respiratory & - & $2(15.3 \%)$ & $1(14.3 \%)$ \\
\hline & Cardiovascular & - & $2(15.3 \%)$ & $0(0 \%)$ \\
\hline & Multi-organ & - & $3(23.3 \%)$ & $5(71.4 \%)$ \\
\hline Death & & $0(0 \%)$ & $0(0 \%)$ & $3(42.9 \%)$ \\
\hline
\end{tabular}

VAS: Visual analog scale.

All prognostic scores evaluated in the study were used to predict moderate and severe pancreatitis according to the revised Atlanta classification. The distribution of prognostic scores according to the revised Atlanta classification is presented in Table 5 . The values of $15 \mathrm{mg} / \mathrm{dL}$ and $0.5 \mathrm{ng} / \mathrm{mL}$ for CRP and procalcitonin were used in reference to previous publications in the literature $(10,15)$. There are different cut-off values in the literature for NLR (14). In the present study, the values of 7.5 on admission and 9.5 at $48^{\text {th }}$ hour were shown to have $50-55 \%$ and 80 $85 \%$ sensitivity and specificity and were used accordingly. In the revised Atlanta classification, the scoring system with the highest correlation coefficient in differentiating moderate and severe pancreatitis is BISAP $(0.443$, moderate correlation). Glasgow-Imrie, ALBI grade $\left(48^{\text {th }} \mathrm{h}\right)$, JSS score, NLR $\geq 7.5$ ( $48^{\text {th }} \mathrm{h}$ ), procalcitonin $\geq 0.5 \mathrm{ng} / \mathrm{mL}$ (on admission), and SOFA score are moderately correlated with the revised Atlanta classification. The ALBI grade 3 (admission) and the HAPS score are weakly correlated. No correlation was found with the Ranson score, APACHE score, CRP $\geq 15 \mathrm{mg} / \mathrm{dL}$ (on admission), NLR $\geq 9.5$ (on admission), CRP $\geq 15 \mathrm{mg} / \mathrm{dL}$ ( $48 \mathrm{~h}$ ), and procalcitonin $\geq 0.5 \mathrm{ng} / \mathrm{mL}$ (48 h).

Prognostic scores correlated with the revised Atlanta classification were examined by uni- and multi-variate regression analysis. In regression analyses, staging was 


\begin{tabular}{|c|c|c|c|c|}
\hline & & $\begin{array}{c}\text { Mild } \\
(n=46)\end{array}$ & $\begin{array}{l}\text { Moderate } \\
(n=13)\end{array}$ & $\begin{array}{l}\text { Severe } \\
(n=7)\end{array}$ \\
\hline \multirow[t]{2}{*}{ Hemoglobin (g/dL) } & Admission & $12.3(9.2-15.8)$ & $12.6(10-14.1)$ & $11.7(10.8-13.5)$ \\
\hline & $48 \mathrm{~h}$ & $12.1(7.7-15.1)$ & $12(9.3-14.7)$ & $12.1(8.9-15.2)$ \\
\hline \multirow[t]{2}{*}{ Leukocyte $\left(10^{3} / \mu \mathrm{L}\right)$} & Admission & $9(2.2-18)$ & $11.1(5-19.6)$ & $9.4(3.8-11.54)$ \\
\hline & $48 \mathrm{~h}$ & $7.47(3.21-15.54)$ & $10.37(4.46-23.95)$ & $7.2(4.06-10.6)$ \\
\hline \multirow[t]{2}{*}{ Neutrophil $\left(10^{3} / \mu \mathrm{L}\right)$} & Admission & $7(1.2-79.2)$ & $9.5(4.3-16.8)$ & $7.3(3-9.84)$ \\
\hline & $48 \mathrm{~h}$ & $4.9(1.3-13.6)$ & $8.7(3.2-21.6)$ & $5.5(2.3-8.4)$ \\
\hline \multirow[t]{2}{*}{ Lymphocyte $\left(10^{3} / \mu \mathrm{L}\right)$} & Admission & $1.23(0.33-9.1)$ & $0.84(0.43-2.75)$ & $0.8(0.36-1.94)$ \\
\hline & $48 \mathrm{~h}$ & $1.6(0.26-2.8)$ & $0.9(0.7-2)$ & $1.3(0.5-1.85)$ \\
\hline \multirow[t]{2}{*}{ NLR } & Admission & $5.6(0.6-32.3)$ & $8.6(5.6-22)$ & $7.3(3.7-24.5)$ \\
\hline & $48 \mathrm{~h}$ & $2.9(1-14.1)$ & $7.5(4-19.1)$ & $3.3(1.4-12)$ \\
\hline \multirow[t]{2}{*}{ Platelet $\left(10^{3} / \mu \mathrm{L}\right)$} & Admission & $213(117-357)$ & $219(105-350)$ & $204(52-482)$ \\
\hline & $48 \mathrm{~h}$ & $210.5(76-350)$ & $175(106-325)$ & $209(165-434)$ \\
\hline \multirow[t]{2}{*}{ Sedimentation $(\mathrm{mm} / \mathrm{h})$} & Admission & $15(3-44)$ & $23(2-45)$ & $42(2-81)$ \\
\hline & $48 \mathrm{~h}$ & $16(0-60)$ & $31(2-72)$ & $32(3-61)$ \\
\hline
\end{tabular}

NLR: Neutrophil-to-lymphocyte ratio.

applied before the multivariate step, and clinical findings, laboratory findings, and prognostic scores were examined in different groups. After multivariate regression, laboratory findings and prognostic scoring systems were subjected to logistical regression together in a combined model (Table 6,7). The presence of ALBI grade 3 at $48^{\text {th }}$ hour increases the risk of moderate and severe pancreatitis by 17 times (Model 1). The presence of antibiotic use increases the risk 6.6 times and positive BISAP score increases the risk 4.7 times (Model 2).

Test statistics and ROC analysis of antibiotic use, procalcitonin $\geq 0.5 \mathrm{ng} / \mathrm{mL}$ (on admission), NLR $\geq 7.5\left(48^{\text {th }} \mathrm{h}\right.$ ), and prognostic scoring systems are presented in Table 8. The highest specificity was obtained in the SOFA score, and the highest sensitivity was obtained in HAPS and BISAP scores. The largest AUC value was observed in the Glasgow-Imrie score. No statistical significance was found between antibiotic use, procalcitonin $\geq 0.5 \mathrm{ng} / \mathrm{mL}$ (on admission), NLR $\geq 7.5$ (48 h), BISAP score, JSS score, and ALBI grade 3 ( $48 \mathrm{~h}$ ) ROC curves included in multivariate regression analysis (DeLong test, data not shown).

\section{DISCUSSION}

Herein, we aimed to evaluate the clinical and laboratory findings and prognostic scores with revised Atlanta classification in patients with acute biliary pancreatitis.
In the present study, the distribution of mild, moderate, and severe pancreatitis was similar to other reports in the literature (3). In particular, severe pancreatitis patient group consisted of patients of advanced age. This observation is also used in almost all scoring systems. Although cut-off values are different, advanced age is integrated as a factor in Ranson, Glasgow-Imrie, JSS, BISAP, and APACHE scoring systems.

It has been demonstrated that moderate or severe pancreatitis according to the revised Atlanta classification is associated with a longer duration of hospitalization, more frequent use of antibiotic therapy, reproduction in blood culture, persistence of pancreatitis pain, and the need for narcotic analgesics. In the context of these data, the present study is the first study in the literature comparing these clinical data with the revised Atlanta classification, which is a consensus for determining the severity of pancreatitis. Identification of moderate and severe pancreatitis is associated not only with the development of organ failure and local complications but also with prolonged hospitalization, development of sepsis, increased pain sensations, and the need for analgesia. In patients with moderate and severe pancreatitis, inflammatory markers such as NLR, procalcitonin, and CRP are elevated. Inflammatory markers are often studied as a standalone indicator, but they are also integrated into scoring systems such as JSS $(6,10,15)$. 


\begin{tabular}{|c|c|c|c|c|}
\hline & & $\begin{array}{c}\text { Mild } \\
(n=46)\end{array}$ & $\begin{array}{l}\text { Moderate } \\
\quad(n=13)\end{array}$ & $\begin{array}{l}\text { Severe } \\
(n=7)\end{array}$ \\
\hline \multirow[t]{2}{*}{ BUN (mg/dL) } & Admission & $14.8(3.47-32)$ & $13.9(8.9-39.2)$ & $19(6.1-25.4)$ \\
\hline & $48 \mathrm{~h}$ & $10.1(5-28.5)$ & $10(3.1-43.7)$ & $17.6(7.7-26.3)$ \\
\hline \multirow[t]{2}{*}{ Creatinine (mg/dL) } & Admission & $0.68(0.37-1.69)$ & $0.83(0.39-8.35)$ & $0.89(0.45-1.41)$ \\
\hline & $48 \mathrm{~h}$ & $0.67(0.2-1.68)$ & $0.69(0.38-6.9)$ & $1(0.62-1.4)$ \\
\hline \multirow[t]{2}{*}{ Albumin (g/dL) } & Admission & $3.8(3.2-4.4)$ & $3.7(3-4.3)$ & $3.7(2.8-4.1)$ \\
\hline & $48 \mathrm{~h}$ & $3.74(3.1-4.3)$ & $3.2(2.4-3.9)$ & $3.6(2.9-4.5)$ \\
\hline \multirow[t]{2}{*}{ AST $(U / L)$} & Admission & $72(9-930)$ & $168(9-372)$ & $86(28-222)$ \\
\hline & $48 \mathrm{~h}$ & $31(13-205)$ & $33(8-265)$ & $44(13-62)$ \\
\hline \multirow[t]{2}{*}{$\operatorname{ALT}(U / L)$} & Admission & $96(10-910)$ & $94(10-459)$ & $3(20-159)$ \\
\hline & $48 \mathrm{~h}$ & $67(8-507)$ & $41(6-301)$ & $50(12-115)$ \\
\hline \multirow[t]{2}{*}{ GGT (U/L) } & Admission & $163.5(10-1.058)$ & $215(20-566)$ & $345(22-759)$ \\
\hline & $48 \mathrm{~h}$ & $125.5(12-821)$ & $148(37-468)$ & $264(17-540)$ \\
\hline \multirow[t]{2}{*}{$\operatorname{ALP}(U / L)$} & Admission & $102(41-815)$ & $148(68-306)$ & $181(102-943)$ \\
\hline & $48 \mathrm{~h}$ & $95(38-714)$ & $121(53-316)$ & $176(107-651)$ \\
\hline \multirow[t]{2}{*}{$\mathrm{LDH}(\mathrm{U} / \mathrm{L})$} & Admission & $275(141-1.207)$ & $340(184-1.392)$ & $269(219-589)$ \\
\hline & $48 \mathrm{~h}$ & $228(139-497)$ & $329(173-982)$ & $229(160-544)$ \\
\hline \multirow[t]{2}{*}{ Total bilirubin (mg/dL) } & Admission & $1(0.1-9.7)$ & $1.7(0.5-5.72)$ & $1.5(0.9-15.1)$ \\
\hline & $48 \mathrm{~h}$ & $0.73(0.3-13.1)$ & $1(0.44-6.41)$ & $1.1(0.3-24.77)$ \\
\hline \multirow[t]{2}{*}{ Direct bilirubin (mg/dL) } & Admission & $0.46(0.01-7.5)$ & $1(0.1-3.7)$ & $0.97(0.2-11.8)$ \\
\hline & $48 \mathrm{~h}$ & $0.23(0.04-10.11)$ & $0.5(0.13-5.02)$ & $0.7(0.1-18)$ \\
\hline \multirow[t]{2}{*}{ Amylase (U/L) } & Admission & $509(39-1.663)$ & $813(39-3.435)$ & $555(101-1.705)$ \\
\hline & $48 \mathrm{~h}$ & $96(23-464)$ & $188(46-848)$ & $152(51-583)$ \\
\hline \multirow[t]{2}{*}{ Lipase (U/L) } & Admission & $657(39-3.458)$ & $1.089(33-3.795)$ & $340(232-548)$ \\
\hline & $48 \mathrm{~h}$ & $93(23-1.504)$ & $101(31-505)$ & $131(64-350)$ \\
\hline \multirow[t]{2}{*}{ CRP (mg/dL) } & Admission & $2.3(0.1-21.4)$ & $6.6(0.8-18.3)$ & $5.38(2.1-15.9)$ \\
\hline & $48 \mathrm{~h}$ & $6.6(0.3-24.7)$ & $15.9(7.9-21.6)$ & $10.3(6.6-18.3)$ \\
\hline \multirow[t]{2}{*}{ Procalcitonin $(\mathrm{ng} / \mathrm{mL})$} & Admission & $0.04(0.01-16.22)$ & $0.46(0.01-17.7)$ & $1.01(0.04-14.23)$ \\
\hline & $48 \mathrm{~h}$ & $0.02(0.01-4.44)$ & $0.16(0.01-31.68)$ & $0.51(0.01-3.53)$ \\
\hline
\end{tabular}

BUN: Blood-urea-nitrogen, AST: Aspartate aminotransferase, ALT: Alanine aminotransferase, GGT: Gamma-glutamyl transferase, ALP: Alkaline phosphatase, LDH: Lactate dehydrogenase, CRP: C-reactive protein.

After the introduction of the revised Atlanta classification in 2012, numerous studies have been conducted on the power of different scoring systems and laboratory parameters to predict the severity of pancreatitis. Ranson and Glasgow-Imrie are older scores, and previous studies have demonstrated that they can predict severe pancreatitis. The biggest criticism of these scores is that they have to be completed in 48 hours, and they are complex. In a retrospective study on 675 patients comparing Ranson and Glasgow-Imrie scores, the Ranson score had $92.7 \%$ sensitivity and $52.8 \%$ specificity in predicting severe acute pancreatitis whereas Glasgow-Imrie score had $76.8 \%$ sensitivity and $69.2 \%$ specificity (18). In the present study, contrary to previous reports, there was no correlation between Ranson scoring and factors associated with both pancreatitis severity and prognosis, whereas a better correlation was found with the Glasgow-Imrie score. The reason for this difference may be due to the fact the patient population in this study consisted only of biliary pancreatitis cases and the frequency of mild pancreatitis cases was higher. 
Table 5. Distribution of prognostic scoring results of patients according to Atlanta classification

\begin{tabular}{|c|c|c|c|c|}
\hline & $\begin{array}{c}\text { Mild } \\
(n=46)\end{array}$ & $\begin{array}{l}\text { Moderate and Severe } \\
\qquad(\mathrm{n}=20)\end{array}$ & $\begin{array}{c}\text { Phi } \\
\text { correl. }\end{array}$ & Phi-p \\
\hline Ranson Score $\geq 3$ & $2(4.3 \%)$ & $3(15 \%)$ & 0.18 & 0.13 \\
\hline Glasgow-Imrie Score $\geq 3$ & $5(10.9 \%)$ & $10(50 \%)$ & 0.429 & 0.001 \\
\hline HAPS Score $\geq 1$ & $17(37 \%)$ & $13(65 \%)$ & 0.259 & 0.035 \\
\hline BISAP Score $\geq 2$ & $9(19.6 \%)$ & $13(65 \%)$ & 0.443 & 0.001 \\
\hline JSS Score $\geq 3$ & $3(6.5 \%)$ & $8(40 \%)$ & 0.413 & 0.001 \\
\hline APACHE Score $\geq 8$ & $21(45.7 \%)$ & $10(50 \%)$ & 0.04 & 0.74 \\
\hline SOFA Score $\geq 4$ & $2(4.3 \%)$ & $5(25 \%)$ & 0.308 & 0.012 \\
\hline ALBI grade 3 (admission) & $7(15.2 \%)$ & $8(40 \%)$ & 0.272 & 0.027 \\
\hline ALBI grade 3 (48 h) & $5(10.9 \%)$ & $10(50 \%)$ & 0.429 & 0.001 \\
\hline CRP $\geq 15$ mg/dL (admission) & $10(21.7 \%)$ & $5(25 \%)$ & 0.03 & 0.77 \\
\hline Procalcitonin $\geq 0.5 \mathrm{ng} / \mathrm{mL}$ (admission) & $9(19.6 \%)$ & $10(50 \%)$ & 0.309 & 0.012 \\
\hline NLR $\geq 9.5$ (admission) & $13(28.3 \%)$ & $7(35 \%)$ & 0.06 & 0.58 \\
\hline CRP $\geq 15 \mathrm{mg} / \mathrm{dL}(48 \mathrm{~h})$ & $14(30.4 \%)$ & $9(45 \%)$ & 0.14 & 0.25 \\
\hline Procalcitonin $\geq 0.5 \mathrm{ng} / \mathrm{mL}(48 \mathrm{~h})$ & $8(17.4 \%)$ & $8(40 \%)$ & 0.24 & 0.05 \\
\hline$N L R \geq 7.5$ (48 h) & $7(15.2 \%)$ & $10(50 \%)$ & 0.36 & 0.003 \\
\hline
\end{tabular}

HAPS: Harmless Acute Pancreatitis Score, BISAP: Bedside Index of Severity in Acute Pancreatitis, JSS: Japanese Severity Score, APACHE: Acute Physiology and Chronic Health Evaluation-II, SOFA: Sequential Organ Failure Assessment, ALBI: Albumin-bilirubin grade, CRP: C-reactive protein, NLR: Neutrophil-to-lymphocyte ratio.

Table 6. The relationship between clinical findings, laboratory findings, and prognostic scores with moderate and severe pancreatitis according to Revised Atlanta classification: regression analysis-I

\begin{tabular}{|c|c|c|c|c|}
\hline & OR $(95 \% \mathrm{CI})$ & $P$ value & Multivariate OR (95\% CI) & $P$ value \\
\hline Antibiotic requirement ${ }^{1}$ & $4.8(2.05-11.4)$ & 0.001 & $6.76(1.3-35.1)$ & 0.02 \\
\hline Culture reproduction ${ }^{1}$ & $7.7(1.7-34.1)$ & 0.007 & NS & - \\
\hline Persistent pain at $48^{\text {th }}$-hour ${ }^{1}$ & $5.92(1.87-18.73)$ & 0.002 & NS & - \\
\hline Use of narcotics ${ }^{1}$ & $9.19(1.12-75.3)$ & 0.038 & NS & - \\
\hline Procalcitonin $\geq 0.5 \mathrm{ng} / \mathrm{mL}$ (admission) ${ }^{2}$ & $4.1(1.3-12.8)$ & 0.015 & $3.7(1.1-12.6)$ & 0.03 \\
\hline$N L R \geq 7.5(48 h)^{2}$ & $5.5(1.69-18.3)$ & 0.005 & $5.15(1.48-17.8)$ & 0.01 \\
\hline Glasgow-Imrie $\geq 3^{3}$ & $8.2(2.28-29.39)$ & 0.001 & NS & - \\
\hline $\mathrm{BISAP} \geq 2^{3}$ & $7.63(2.36-24.66)$ & 0.001 & $4.81(1.12-20.6)$ & 0.034 \\
\hline $\mathrm{HAPS} \geq 1^{3}$ & $3.16(1.05-9.48)$ & 0.039 & NS & - \\
\hline$J S S \geq 3^{3}$ & $9.55(2.1-41.6)$ & 0.003 & $7.18(1.17-43.7)$ & 0.03 \\
\hline SOFA $\geq 4^{3}$ & $7.33(1.28-41.83)$ & 0.024 & NS & - \\
\hline ALBI grade 3 (admission) ${ }^{3}$ & $3.71(1.1-12.3)$ & 0.03 & NS & - \\
\hline ALBI grade $3(48 h)^{3}$ & $8.2(2.28-29.3)$ & 0.001 & $11.8(2.52-55)$ & 0.002 \\
\hline
\end{tabular}

Univariate logistic regression. Superscript figures refer to groups that were included in the multivariate analysis.

1: Clinical findings group, 2: Laboratory findings group. ${ }^{3}$ : Prognostic scores group. NLR: Neutrophil-to-lymphocyte ratio. BISAP: Bedside Index of Severity in Acute Pancreatitis, HAPS: Harmless Acute Pancreatitis Score, JSS: Japanese Severity Score, SOFA: Sequential Organ Failure Assessment, ALBI: Albumin-bilirubin grade, OR: Odds ratio. $\mathrm{Cl}$ : Confidence interval. NS: Not significant. 
Table 7. The relationship between clinical findings, laboratory findings, and prognostic scores with moderate and severe pancreatitis according to revised Atlanta classification: regression analysis-II

\begin{tabular}{|c|c|c|c|c|}
\hline & $\begin{array}{c}\text { Model } 1 \\
\text { OR }(95 \% \mathrm{Cl})\end{array}$ & $P$ value & $\begin{array}{c}\text { Model } 2 \\
\text { OR }(95 \% \mathrm{Cl})\end{array}$ & P value \\
\hline Antibiotic requirement ${ }^{1}$ & NS & - & $6.64(1.28-34.3)$ & 0.02 \\
\hline Procalcitonin $\geq 0.5 \mathrm{ng} / \mathrm{mL}$ (admission) ${ }^{2}$ & NS & - & NS & - \\
\hline$N L R \geq 7.5(48 h)^{2}$ & NS & - & NS & - \\
\hline $\mathrm{BISAP} \geq 2^{3}$ & NS & - & $4.7(1.34-16.4)$ & 0.015 \\
\hline$J S S \geq 3^{3}$ & NS & - & NS & - \\
\hline ALBI grade $3(48 h)^{3}$ & $17.4(3.1-97.3)$ & 0.001 & $\mathrm{NI}$ & - \\
\hline
\end{tabular}

Multivariate logistic regression. ': Clinical findings group, 2: Laboratory findings group. 3: Prognostic scores group. NLR: Neutrophil-to-lymphocyte ratio. BISAP: Bedside Index of Severity in Acute Pancreatitis, JSS: Japanese Severity Score, ALBI: Albumin-bilirubin grade, OR: Odds ratio. Cl: Confidence interval. NS: Not significant. NI: Not included.

Table 8. The relationship between clinical findings, laboratory findings, and prognostic scores and moderate and severe pancreatitis according to the revised Atlanta classification: Test statistics and ROC analysis

\begin{tabular}{|c|c|c|c|c|}
\hline & Sensitivity & Specificity & $\operatorname{AUC}(95 \% \mathrm{Cl})$ & $P$ value \\
\hline Antibiotherapy requirement & $54 \%$ & $90 \%$ & $0.72(0.59-.084)$ & 0.004 \\
\hline Procalcitonin $\geq 0.5 \mathrm{ng} / \mathrm{mL}$ (admission) & $50 \%$ & $80.4 \%$ & $0.65(0.51-0.8)$ & 0.05 \\
\hline$N L R \geq 7.5(48 h)$ & $50 \%$ & $84.7 \%$ & $0.67(0.52-0.82)$ & 0.026 \\
\hline Ranson $\geq 3$ & $15 \%$ & $95.6 \%$ & $0.66(0.52-0.8)$ & 0.039 \\
\hline Glasgow-Imrie $\geq 3$ & $50 \%$ & $89.1 \%$ & $0.81(0.69-0.92)$ & 0.001 \\
\hline BISAP $\geq 2$ & $65 \%$ & $80.4 \%$ & $0.75(0.61-0.89)$ & 0.001 \\
\hline HAPS $\geq 1$ & $65 \%$ & $63 \%$ & $0.64(0.49-0.78)$ & 0.072 \\
\hline$J S S \geq 3$ & $40 \%$ & $93.4 \%$ & $0.667(0.54-0.84)$ & 0.012 \\
\hline APACHE $\geq 8$ & $50 \%$ & $54.3 \%$ & $0.59(0.44-0.74)$ & 0.236 \\
\hline SOFA $\geq 4$ & $25 \%$ & $95.6 \%$ & $0.66(0.52-0.81)$ & 0.032 \\
\hline ALBI grade 3 (admission) & $40 \%$ & $84.7 \%$ & $0.62(0.54-0.84)$ & 0.112 \\
\hline ALBI grade 3 (48 h) & $50 \%$ & $89.1 \%$ & $0.69(0.51-0.82)$ & 0.012 \\
\hline
\end{tabular}

NLR: Neutrophil-to-lymphocyte ratio. BISAP: Bedside Index of Severity in Acute Pancreatitis, HAPS: Harmless Acute Pancreatitis Score, JSS: Japanese Severity Score, APACHE: Acute Physiology and Chronic Health Evaluation-II, SOFA: Sequential Organ Failure Assessment, ALBI: Albumin-bilirubin grade. AUC: Area under curve. CI: Confidence interval. P values of ROC curves are presented.

JSS, a Japanese scoring system, was modified in 2008, and it is an original scoring system as it integrates 9 prognostic factors as well as contrast-enhanced abdominal tomography findings. Although studies on JSS are limited, in a study of 17901 patients, the AUC of JSS for predicting intra-hospital mortality was $0.798(95 \% \mathrm{Cl}$ 0.775-0.821) (10). In a study comparing HAPS, Ranson, BISAP, Glasgow, and JSS's ability to predict important adverse events in the hospital, 30-day mortality and 30day readmission rate, JSS was found to be the superior scoring system (19). Previous studies have reported re- sults similar to our findings for predicting the severity of pancreatitis (20).

Unlike Ranson and Glasgow-Imrie scores, BISAP is a prognostic score that is developed for faster patient separation on admission. Two different studies in the literature have indicated that BISAP scores predict the severity of pancreatitis, pancreatic necrosis, and mortality at similar levels to APACHE and Ranson $(21,22)$. In another study involving a higher rate of (35.2\%) severe pancreatitis, BISAP was more powerful in predicting severe acute 
pancreatitis, pancreatic necrosis, and mortality compared to the Ranson score (22). The sensitivity and specificity of the BISAP score in predicting pancreatitis severity was 51\% (43-60\%) and 91\% (89-92\%), respectively. Although the sensitivity of BISAP was lower compared to APACHE and Ranson scores, its specificity was higher (8). In the present study, BISAP score had a lower specificity but better sensitivity in predicting moderate and severe acute pancreatitis compared to Ranson score. The reason for this difference may be due to the patient population included in the study consisting only of biliary pancreatitis cases, the application of different cut-off values for APACHE in different studies, and the higher frequency of mild pancreatitis cases in the present study. In addition, except for the ALBI grade, the BISAP score stands out as an independent prognostic factor in predicting moderate and severe pancreatitis in multivariate analyses.

Unlike other scores, HAPS is a scoring system designed to differentiate mild pancreatitis. Literature data is limited because it is more recent compared to other scoring systems and its objective is different. In a study of 116 patients where the HAPS score was compared to the Ranson score, HAPS predicted the severity of the disease in 101 (87\%) patients with a sensitivity of $98 \%$ and a specificity of $77 \%$ (23). In another study of 144 patients, HAPS predicted mild pancreatitis with $81 \%$ specificity and $96 \%$ positive predictive value, while the predictive power of the Ranson score was not statistically significant (24). In the present study, HAPS score had $63 \%$ sensitivity and $65 \%$ specificity in predicting moderate or severe acute pancreatitis. This may be due to the fact that, unlike other studies in the literature, the patient population included in this study contains a higher ratio of moderate and severe pancreatitis.

Along with being a score used to predict grading and survival in patients with hepatocellular cancer, a current study has stated that ALBI may be an independent prognostic factor for critically-ill pancreatitis patients. 284 patients were evaluated and 35 patients died during this study, and it was found that ALBI was better than SOFA, SAPS-II, APACHE-II, Ranson score, and Glasgow-Imrie score (13). In the present study, ALBI grade 3 was found to be an independent prognostic factor in multivariate analyses for predicting moderate and severe pancreatitis, especially in ALBI grade 3 patients at $48^{\text {th }}$ hour.

However, the use of ALBI grade for this purpose in acute biliary pancreatitis may lead to an inherent bias, since acute biliary pancreatitis is often a secondary negative acute phase to hyperbilirubinemia and inflammation, and thus characterized by hypoalbuminemia.

In addition to prognostic scoring systems, there are comparative studies showing that acute phase indicators such as neutrophil lymphocyte ratio (NLR), C-reactive protein (CRP), and procalcitonin levels can also predict severe acute pancreatitis, pancreatic necrosis, organ failure, and mortality. The sensitivity of NLR to predict severe acute pancreatitis ranges from $77-82 \%$. Although different values were reported for optimal cut-off, 63-90\% sensitivity and $50-57 \%$ specificity were reported in predicting severe acute pancreatitis $(14,25)$. In a study of 75 patients -of which 12 had severe acute pancreatitis- while investigating the predictive power of procalcitonin levels on severe acute pancreatitis, it was found that procalcitonin levels on admission and at $48^{\text {th }}$ hour had limited predictive power on biliary pancreatitis and severe pancreatitis (26). However, in another study on 50 patients, the predictive power of procalcitonin levels determined by strip test for duration of hospitalization, the need for intensive care, the necessity of antibiotic therapy, and the development of severe acute pancreatitis was examined, and it was found that procalcitonin levels showed higher correlation than CRP and leukocyte levels (15). In the present study, cut-off value of NLR at $48^{\text {th }}$ hour for predicting the severity of pancreatitis was 7.48, and its predictive power was shown to be at a level consistent with other studies in the literature. Procalcitonin levels are higher in moderate and severe pancreatitis, both at the time of admission and at $48^{\text {th }}$ hour. However, the findings are far from definitive, and further studies are needed.

It can be said that there is no single ideal scoring system or laboratory finding for predicting the severity of pancreatitis. In the present study, BISAP was the scoring system with the highest correlation coefficient in differentiating moderate and severe pancreatitis using the revised Atlanta classification (0.443, moderate correlation). BISAP was followed by Glasgow-Imrie score and ALBI grade, but no scoring system indicated a strong correlation with the revised Atlanta classification. In multivariate regression analysis, ALBI grade 3 at 48th hour increased the risk for moderate and severe pancreatitis according to Revised Atlanta Classification 17 times; however, as previously mentioned, this scoring system may have a bias for biliary pancreatitis. BISAP score has $65 \%$ sensitivity, $80.4 \%$ specificity, and 0.75 (0.61-0.89) AUC in predicting moderate and severe pancreatitis, and within the available scoring systems, it appears to be the most suitable candidate in terms of routine clinical use in terms of diagnostic test values, ease of use, factors included, and the fact that it 
can be completed on admission. Moreover, the combined use of BISAP and antibiotics use is a novel option in clinic settings for predicting moderate and severe pancreatitis.

There are certain limitations of the present study. Due to its retrospective design, patients with incomplete data were not evaluated; therefore, the study was conducted with a limited sample. However, despite the limited number of patients included, many different scoring systems were evaluated with a homogeneous group of patients.

There is no consensus regarding an ideal scoring system in predicting the severity of pancreatitis. The use of multiple scoring systems or co-evaluation of laboratory data can increase the sensitivity and specificity of clinical decisions. According to the results of the present study, the combined use of BISAP and antibiotic therapy requirement is a potential candidate for predicting moderate and severe pancreatitis. Further studies on the

\section{REFERENCES}

1. Iannuzzi J, Leung J, Quan J, Underwood F. Global incidence of acute pancreatitis through time: A aystematic review. J Can Assoc Gastroenterol 2019;2:499-501.

2. Xiao AY, Tan MLY, Wu LM, et al. Global incidence and mortality of pancreatic diseases: a systematic review, meta-analysis, and meta-regression of population-based cohort studies. Lancet Gastroenterol Hepatol 2016;1:45-55.

3. Banks PA, Bollen TL, Dervenis $C$, et al. Classification of acute pancreatitis - 2012: Revision of the Atlanta classification and definitions by international consensus. Gut 2013;62:102-11.

4. Singh VK, Bollen TL, Wu BU, et al. An Assessment of the severity of interstitial pancreatitis. Clin Gastroenterol Hepatol 2011;9:1098103.

5. Vege SS, Gardner TB, Chari ST, et al. Low mortality and high morbidity in severe acute pancreatitis without organ failure: A case for revising the Atlanta classification to include "moderately severe acute pancreatitis." Am J Gastroenterol 2009;104:710-5.

6. Mofidi R, Duff MD, Wigmore SJ, et al. Association between early systemic inflammatory response, severity of multiorgan dysfunction and death in acute pancreatitis. Br J Surg 2006;93:738-44.

7. De Bernardinis $M$, Violi $V$, Roncoroni L, et al. Discriminant power and information content of Ranson's prognostic signs in acute pancreatitis: A meta-analytic study. Crit Care Med 1999;27:2272-83.

8. Gao W, Yang HX, Ma CE. The value of BISAP score for predicting mortality and severity in acute pancreatitis: A systematic review and meta-analysis. PLoS One 2015;10:e0130412.

9. Oskarsson V, Mehrabi M, Orsini N, et al. Validation of the harmless acute pancreatitis score in predicting nonsevere course of acute pancreatitis. Pancreatology 2011;11:464-8.

10. Hamada $T$, Yasunaga $H$, Nakai $Y$, et al. Japanese severity score for acute pancreatitis well predicts in-hospital mortality: A nationwide survey of 17,901 cases. J Gastroenterol 2013;48:1384-91.

11. Karabıyık L. Intensive care scoring systems. Yoğun Bakım Derg 2010;9:129-43. use of ALBI grade, especially in the group of acute biliary pancreatitis, are necessary. In the acute pancreatitis group, studies specific to biliary pancreatitis and further studies aimed at investigating other prognostic factors other than pancreatitis severity such as sepsis, the use of antibiotics, the need for analgesia, and the duration of hospitalization are needed.

Statements: This study was conducted as an Internal Medicine Specialty Thesis project.

Conflicts of interest: All authors declare no conflicts of interest.

\section{Previous presentations or publications: None.}

Ethics: This study was conducted in accordance with the Declaration of Helsinki. Ethics committee approval was received from Akdeniz University Faculty of Medicine Ethics Committee (30.05.2018/382). Informed consent was obtained from the patients for the use of information.
12. Juneja D, Gopal PB, Ravula M. Scoring systems in acute pancreatitis: Which one to use in intensive care units? J Crit Care 2010;25:358. e9-358.e15.

13. Shi L, Zhang D, Zhang J. Albumin-bilirubin score is associated with in-hospital mortality in critically ill patients with acute pancreatitis. Eur J Gastroenterol Hepatol 2020;32:963-70

14. Suppiah A, Malde D, Arab T, et al. The prognostic value of the neutrophil-lymphocyte ratio (NLR) in acute pancreatitis: Identification of an optimal NLR. J Gastrointest Surg 2013;17:675-81.

15. Dias $B H$, Rozario AP, Olakkengil SA, et al. Procalcitonin strip test as an independent predictor in acute pancreatitis. Indian J Surg 2015;77:1012-7.

16. Svendsen K, Borchgrevink PC, Fredheim O, et al. Choosing the unit of measurement counts: The use of oral morphine equivalents in studies of opioid consumption is a useful addition to defined daily doses. Palliat Med 2011;25:725-32.

17. Imrie CW, Benjamin IS, Ferguson JC, et al. A single-centre doubleblind trial of Trasylol therapy in primary acute pancreatitis. Br J Surg 1978;65:337-41.

18. Kiat TTJ, Gunasekaran SK, Junnarkar SP, et al. Are traditional scoring systems for severity stratification of acute pancreatitis sufficient? Ann Hepato-Biliary-Pancreatic Surg 2018;22:105-15.

19. Biberci Keskin E, Taşlıdere B, Koçhan K, et al. Comparison of scoring systems used in acute pancreatitis for predicting major adverse events. Gastroenterol Hepatol 2020;43:193-9.

20. Hong W, Lillemoe KD, Pan S, et al. Development and validation of a risk prediction score for severe acute pancreatitis. J Transl Med 2019;17:146.

21. Zhang J, Shahbaz M, Fang R, et al. Comparison of the BISAP scores for predicting the severity of acute pancreatitis in Chinese patients according to the latest Atlanta classification. J Hepatobiliary Pancreat Sci 2014;21:689-94.

22. Papachristou GI, Muddana V, Yadav D, et al. Comparison of BISAP, Ranson's, APACHE-II, and CTSI scores in predicting organ failure, complications, and mortality in acute pancreatitis. Am J Gastroenterol 2010;105:435-41. 
23. Al-Qahtani HH, Alam MKh, Waheed M. Comparison of Harmless Acute Pancreatitis Score with Ranson's Score in predicting the severity of acute pancreatitis. J Coll Physicians Surg Pak 2017;27:759.

24. Sayraç AV, Cete Y, Yiğit Ö, et al. Utility of HAPS for predicting prognosis in acute pancreatitis. Ulus Travma ve Acil Cerrahi Derg 2018;24:327-32.
25. Han C, Zeng J, Lin R, et al. The utility of neutrophil to lymphocyte ratio and fluid sequestration as an early predictor of severe acute pancreatitis. Sci Rep 2017;7:10704

26. Modrau IS, Floyd AK, Thorlacius-Ussing O. The clinical value of procalcitonin in early assessment of acute pancreatitis. Am J Gastroenterol 2005;100:1593-7. 